\title{
Changes in composition, antioxidant content, and antioxidant capacity of coffee pulp during the ensiling process
}

\section{Teodulo Salinas Rios ${ }^{1}$, Teresa Sánchez Torres ${ }^{1}$, María Esther Ortega Cerrilla ${ }^{1}$, Marcos Soto Hernández ${ }^{2}$, Antonio Díaz Cruz ${ }^{3}$, Jorge Hernández Bautista ${ }^{4}$, Cuauhtémoc Nava Cuéllar ${ }^{2}$, Humberto Vaquera Huerta ${ }^{5}$}

\footnotetext{
1 Programa de Ganadería, Colegio de Postgraduados, Campus Montecillo, México.

2 Programa de Botánica, Colegio de Postgraduados, Campus Montecillo, México.

${ }^{3}$ Departamento de Nutrición Animal y Bioquímica, Universidad Nacional Autónoma de México, Distrito Federal, México.

${ }^{4}$ Facultad de Medicina Veterinaria y Zootecnia, Universidad Autónoma Benito Juárez de Oaxaca, Oaxaca, México.

${ }^{5}$ Programa de Estadística, Colegio de Postgraduados, Campus Montecillo, México.
}

\begin{abstract}
The objective of the present study was to determine the nutritive value, the presence of antioxidant compounds, and the antioxidant capacity of coffee pulp ensiled or non-ensiled. Dry matter (DM), crude protein (CP), ash, acid detergent fiber (ADF), neutral detergent fiber (NDF), and lignin, as well as the antioxidant compounds present in coffee pulp and their antioxidant capacity, were determined. A completely randomized design was used. Data were analyzed by analysis of variance. Ensiling of coffee pulp increased the CP content from 98.6 to $111.6 \mathrm{~g} \mathrm{~kg}^{-1} \mathrm{DM}$, NDF from 414.6 to $519.5 \mathrm{~g} \mathrm{~kg}^{-1} \mathrm{DM}$, ADF from 383.9 to $439.3 \mathrm{~g} \mathrm{~kg}^{-1} \mathrm{DM}$, and lignin from 122.9 to $133.6 \mathrm{~g} \mathrm{~kg}^{-1} \mathrm{DM}$. Caffeine decreased from 5.72 to $5.02 \mathrm{mg} \mathrm{g}^{-1} \mathrm{DM}$. Three antioxidant compounds were detected. Caffeic acid decreased due to ensiling (16.49 vs $\left.14.69 \mathrm{mg} \mathrm{g}^{-1} \mathrm{DM}\right)$. Gallic acid (2.88 vs $\left.2.58 \mathrm{mg} \mathrm{g}^{-1} \mathrm{DM}\right)$ and chlorogenic acid (62.12 vs $\left.56.00 \mathrm{mg} \mathrm{g}^{-1} \mathrm{DM}\right)$ did not differ, and there was similar antioxidant capacity of non-ensiled $\left(215.66 \mu \mathrm{mol}\right.$ trolox $\left.\mathrm{g}^{-1} \mathrm{DM}\right)$ and ensiled coffee pulp $\left(206.59 \mu \mathrm{mol}\right.$ trolox $\left.\mathrm{g}^{-1} \mathrm{DM}\right)$. Despite the decrease in the caffeic acid content due to the ensiling process, it is possible to use either ensiled or non-ensiled coffee pulp for animal feeding because of its high antioxidant capacity.
\end{abstract}

Key Words: caffeic, caffeine, chlorogenic, gallic acid, silage, trolox

\section{Introduction}

Coffee is one of the most consumed beverages in the world. Pulping yields $400 \mathrm{~g}$ coffee pulp/kg cherry, which might represent a source of pollution of rivers and streams. Coffee pulp has been used as animal feed. Weight gain, feed intake, and feed efficiency have been evaluated in pigs (Barrueta et al., 2000), sheep (Furuscho Garcia et al., 2000), and fish (Bautista et al., 2005), proving that it is possible to use it, although the amount used should be limited because of the presence of certain antinutritional factors such as caffeine and tannins. Different methods have been used to reduce the caffeine content (Mazzafera, 2002; Tagliari et al., 2003; Orozco et al., 2008); however, its application has been difficult due to the large amounts of pulp generated by coffee cherry pulping.

Given the high moisture content and fast decomposition of the coffee pulp, an option to preserve it is by ensiling

Received August 21, 2013 and accepted March 25, 2014.

Corresponding author: teresa@colpos.mx

http://dx.doi.org/10.1590/S1516-35982014000900006

Copyright (@) 2014 Sociedade Brasileira de Zootecnia. This is an Open Access article distributed under the terms of the Creative Commons Attribution Non-Commercial License, which permits unrestricted non-commercial use, distribution, and reproduction in any medium, provided the original work is properly cited. with molasses (Ulloa Rojas et al., 2003). On the other hand, coffee-based drinks have proven to have a great antioxidant activity (Richelle et al., 2001). This activity is due to the great amount of phenolic compounds present in the coffee grain (Farah and Donangelo, 2006), which decreases depending on the type of roasting, which might decrease polyphenol concentrations (Castillo et al., 2002; Duarte et al., 2005). Like the grain, coffee pulp has been attributed with a few antioxidant properties (Arellano-González et al., 2011) and it is possible that some handling practices alter its antioxidant capacity. Besides the profile of the antioxidants and their antioxidant capacity, it could help to decrease oxidative stress in animals. However, it is necessary to determine if ensiling can affect its chemical characteristics; therefore, the objective of this research was to determine the nutritional value, antioxidant compounds, and antioxidant capacity of coffee pulp non-ensiled or ensiled with $50 \mathrm{~g}$ molasses $\mathrm{kg}^{-1}$ fresh pulp.

\section{Material and Methods}

The present study was conducted according to the norms of ethics and biosafety of Colegio de Postgraduados, Campus Montecillo, México. 
Coffee cherries (Coffea Arabica) were harvested in the municipality of San Juan Lachao, Oaxaca, Mexico, located at $16^{\circ} 09^{\prime}$ north and $97^{\circ} 07^{\prime}$ west, $1000 \mathrm{~m}$ altitude, with a mean annual precipitation of $2200 \mathrm{~mm}$ (INEGI, 2011). The cherries were wet-processed within 12 hours after harvesting. The pulp remained lying for 12 hours to lose excess water acquired during pulping. Later, the pulp was mixed with $50 \mathrm{~g}$ molasses $\mathrm{kg}^{-1}$ pulp and ensiled in eight plastic containers, $200-\mathrm{kg}$ capacity each. Fermentation lasted 60 days. Fifty grams of molasses $\mathrm{kg}^{-1}$ pulp were used because there are references which indicate that it improves the nutritional value and ensures good fermentation (Ulloa Rojas et al., 2003). The study consisted of two treatments: non-ensiled coffee pulp and ensiled coffee pulp with $50 \mathrm{~g}$ of molasses kg-1 fresh pulp. At the end of the ensiling process, the $\mathrm{pH}$ of the fermented coffee pulp was measured. Three samples of $1.50 \mathrm{~kg}$ were collected per container before and after ensiling (top, middle, and bottom of the container), and mixed to obtain a single sample per container. These samples were divided into three sub-samples.

The first sub-sample was dehydrated at $55{ }^{\circ} \mathrm{C}$ in a forced-air oven for three days and was used to determine dry matter (DM), ash, crude protein (CP) (AOAC, 1990), neutral detergent fiber (NDF), acid detergent fiber (ADF), and lignin contents (Van Soest et al., 1991).

The second sample was used to determine volatile fatty acids and lactic acid. Twenty grams of fresh material were weighed and $20 \mathrm{~mL}$ distilled water was added. The sample was blended, filtered, and mixed in a 4:1 proportion with metaphosphoric acid at $25 \%$. Volatile fatty acids were determined using the Erwin et al. (1961) technique, and lactic acid through the modified Taylor (1996) technique.

The third sample was freeze-dried at $-55^{\circ} \mathrm{C}$ for 5 days. One gram of the freeze-dried sample was weighed and $5 \mathrm{~mL}$ $\mathrm{H}_{2} \mathrm{O}$ were added; it was shaken for $20 \mathrm{~min}$ then centrifuged at $5,000 \mathrm{rpm}$ for 10 minutes and the supernatant was gathered. This aqueous extract was filtered through a nylon acrodisc with $0.45 \mu \mathrm{m}$ pores, and then injected in an Agylen Technologies liquid chromatograph (model 1100) equipped with an Agylen Technologies diode and automatic injector set (model 1200). The column used was a Nucleosil $100 \mathrm{~A}$, $125 \times 4.00 \mathrm{~mm}$ particle size. To determine the antioxidant compounds present in the coffee pulp, the gradient analysis was carried out using methanol in A and 5\% formic acid in $\mathrm{H}_{2} \mathrm{O}$ in $\mathrm{B}$. Flow speed was $1.50 \mathrm{~mL}$ per minute at $25^{\circ} \mathrm{C}$, injecting $20 \mu \mathrm{L}$ sample and reading at $280 \mathrm{~nm}$. Ten Sigma-brand acids with antioxidant properties were used to build the standard curve: gallic, chlorogenic, syringic, vanillic, 2-5-dihidroxibenzoic, caffeic, p-hidroxibenzoic, 2-3-dihidroxibenzoic, ferulic, and p-coumaric.
To determine the amount of caffeine present in the pulp, an isocratic analysis was performed using water and HPLC degree acetonitrile in a 75:25 ratio. Ten microliters of the sample were injected at a flow rate of $0.80 \mathrm{~mL}$ per minute, $25^{\circ} \mathrm{C}$ and reading at 273 nanometers. To build the standard curve, Merck brand caffeine was used as the standard.

To measure the antioxidant capacity, the same subsample for detecting antioxidant compounds and caffeine was used. Before measuring the antioxidant capacity, a sample extract was obtained following the technique described by Restrepo-Sánchez et al. (2009) with some adaptations, $0.50 \mathrm{~g}$ coffee pulp was weighed, rinsed with $10 \mathrm{~mL}$ methanol at $50 \%$ in water, and acidified with $\mathrm{HCl} 2 \mathrm{~N}$ at a pH of 2 . It was later shaken for $1 \mathrm{~h}$ at $37^{\circ} \mathrm{C}$ and centrifuged at $3000 \mathrm{rpm}$ for 15 minutes at $4{ }^{\circ} \mathrm{C}$. The supernatant was collected and the precipitate was treated with a mixture of $70 \%$ acetone and $30 \%$ water, shaken and centrifuged as with the first dilution. This second supernatant was collected and mixed with the first. The antioxidant capacity was measured using the FRAP technique (ferrous reduction antioxidizing power) by Benzie and Strain (1999). The modification was that the samples were incubated, shaking, for $20 \mathrm{~min}$, and then measured in a spectrophotometer at 593 nanometers. The interpretation of the pattern curves was performed with different trolox (6-hidroxi-2-5-7-8-tetramethyl-croman-2carboxilic acid) concentrations, which is a water soluble equivalent of vitamin $\mathrm{E}$.

A completely randomized design was used with two treatments: non-ensiled coffee pulp and ensiled coffee pulp, with eight repetitions per treatment. The experimental units were the containers. Data were analyzed by analysis of variance, considering the containers where the pulp was ensiled as a block. The SAS (Statistical Analysis System, version 9) software was used. The model used was:

$$
\mathrm{Y}_{i j}=\mu+\tau_{i}+\beta_{j}+\varepsilon_{i j}
$$

in which: $\mathrm{Y}_{i j}=$ response variable of the $i$-th treatment in the $j$-th container, $\mu=$ overall mean, $\tau_{i}=$ effect of the $i$-th treatment, $\beta_{j}=$ effect of the $j$-th container; and $\varepsilon_{i j}=$ random error.

\section{Results}

The $\mathrm{pH}$ of the pulp after two months of fermentation was 4.16. Acetic acid was found at $18.54 \mathrm{~g} \mathrm{~kg}^{-1} \mathrm{DM}$ in the silage; neither propionic nor butyric acid was detected (Table 1).

The composition of the nutrients found in the coffee pulp ensiled and non ensiled (Table 2) shows that coffee pulp with $50 \mathrm{~g}$ molasses $\mathrm{kg}^{-1}$ pulp contained $764.02 \mathrm{~g} \mathrm{~kg}^{-1}$ moisture. Despite having a low amount of dry matter, the 
silage did not spoil or present bad odors. The ash percentage for coffee did not differ $(\mathrm{P}>0.05)$ between ensiled and nonensiled pulp. With regard to the $\mathrm{CP}$ percentage, it was greater $(\mathrm{P}<0.05)$ in the ensiled $\left(111.6 \mathrm{~g} \mathrm{~kg}^{-1} \mathrm{DM}\right)$ than the non-ensiled (98.6 $\mathrm{g} \mathrm{kg}^{-1} \mathrm{DM}$ ) coffee pulp. The neutral detergent fiber increased from 414.60 to $519.50 \mathrm{~g} \mathrm{~kg}^{-1} \mathrm{DM}(\mathrm{P}<0.05)$, while ADF increased from 383.90 to $439.30 \mathrm{~g} \mathrm{~kg}^{-1} \mathrm{DM}(\mathrm{P}<0.05)$ after ensiling. The lignin percentage increased by $1.07 \%$ of the total DM $(\mathrm{P}<0.05)$ (Table 2).

Ensiling decreased $(\mathrm{P}<0.05)$ the amount of caffeine from $5.72 \mathrm{mg} \mathrm{g}^{-1}$ to $5.02 \mathrm{mg} \mathrm{g}^{-1} \mathrm{DM}$ coffee pulp (Table 3). The caffeic acid concentration decreased due to the ensiling process $(\mathrm{P}<0.05)$ from $16.49 \mathrm{mg} \mathrm{g}^{-1}$ to $14.69 \mathrm{mg} \mathrm{g}^{-1}$, while ensiling had no effect on gallic and chlorogenic acids $(\mathrm{P}>0.05)$. Despite the decrease in the concentration of caffeic acid, the antioxidant capacity value measured by the ferrous reduction technique (FRAP) was similar $(\mathrm{P}>0.05)$ in non-ensiled coffee pulp $\left(215.66 \mu \mathrm{mol}\right.$ trolox $\left.\mathrm{g}^{-1} \mathrm{DM}\right)$ and ensiled coffee pulp with $5 \mathrm{mg}$ molasses $\mathrm{kg}^{-1}$ pulp (206.59 $\mu$ mol trolox $\mathrm{g}^{-1} \mathrm{DM}$ ) (Table 3).

Table 1 - Values ( \pm SE) for $\mathrm{pH}$, lactic acid, and concentration of volatile fatty acids in coffee pulp ensiled for 60 days

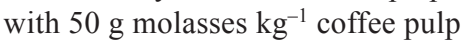

\begin{tabular}{lc}
\hline Characteristic & Value \\
\hline $\mathrm{pH}$ & $4.16 \pm 0.06$ \\
Acetic acid $\left(\mathrm{g} \mathrm{kg}^{-1} \mathrm{DM}\right)$ & $18.54 \pm 1.34$ \\
Propionic acid $\left(\mathrm{g} \mathrm{kg}^{-1} \mathrm{DM}\right)$ & Not detected \\
Butyric acid $\left(\mathrm{g} \mathrm{kg}^{-1} \mathrm{DM}\right)$ & Not detected \\
Lactic acid $\left(\mathrm{g} \mathrm{kg}^{-1} \mathrm{DM}\right)$ & $47.38 \pm 1.64$ \\
\hline
\end{tabular}

SE - standard error.

\section{Discussion}

The $\mathrm{pH}$ of the pulp after two months of fermentation was near 4, where bacterial growth is inhibited (Ryser et al., 1997). However, $\mathrm{pH}$ values greater than 4.50 have been reported for barley, with high values of lactic and acetic acid, which indicates good fermentation (Hristov and McAllister, 2002). Despite the high moisture content in the silage, because there was no butyric acid, the coffee pulp silage did not have unpleasant smell or taste, which might have been rejected by the animals. A high value of lactic acid (47.38 $\mathrm{g} \mathrm{kg}^{-1} \mathrm{DM}$ ) was found, higher than those found for corn and sorghum silage (Juarena, 2008). The high content of lactic acid indicates that there were enough soluble carbohydrates in the coffee pulp, which has a sweet taste due to the presence of a great amount of sugars, besides the $50 \mathrm{~g}$ molasses $\mathrm{kg}^{-1}$ pulp that was added, thus increasing the content of soluble carbohydrates. Because of this, it is essential to determine if it is necessary to add molasses to the coffee pulp before ensiling, or if its addition can be omitted for practical and economic reasons.

The ash values were higher than those found by Figueroa and Mendoza (2010), who reported an average of $66 \mathrm{~g} \mathrm{~kg}^{-1}$, and those found by Bautista et al. (2005), who reported $74 \mathrm{~g} \mathrm{~kg}^{-1}$ for unfermented coffee pulp and $69 \mathrm{~g} \mathrm{~kg}^{-1}$ for coffee pulp ensiled with $50 \mathrm{~g}$ molasses $\mathrm{kg}^{-1}$ coffee pulp. The high ash values found in this study could be due to the hand-picked method and the pulping process, where it could have been contaminated with different minerals from the soil.

Table 2 - Coffee pulp composition before and after ensiling with $50 \mathrm{~g}$ molasses $\mathrm{kg}^{-1}$ coffee pulp

\begin{tabular}{|c|c|c|c|c|}
\hline \multirow{2}{*}{ Nutrient } & \multicolumn{2}{|c|}{ Treatments } & \multirow{2}{*}{ SEM } & \multirow{2}{*}{ P-value } \\
\hline & Non-ensiled coffee pulp $\left(\mathrm{g} \mathrm{kg}^{-1} \mathrm{DM}\right)$ & Ensiled coffee pulp ( $\left.\mathrm{g} \mathrm{kg}^{-1} \mathrm{DM}\right)$ & & \\
\hline Moisture & 764.02 & 781.04 & 7.56 & 0.234 \\
\hline Ash & 145.60 & 144.70 & 5.20 & 0.901 \\
\hline Crude protein & $98.60 \mathrm{~b}$ & $111.66 \mathrm{a}$ & 1.68 & $<0.0001$ \\
\hline Neutral detergent fiber & $414.60 \mathrm{~b}$ & $519.50 \mathrm{a}$ & 10.17 & 0.0014 \\
\hline Acid detergent fiber & $383.90 b$ & $439.30 \mathrm{a}$ & 9.40 & $<0.0001$ \\
\hline Lignin & $122.92 b$ & $133.68 \mathrm{a}$ & 3.02 & 0.027 \\
\hline
\end{tabular}

$\mathrm{a}, \mathrm{b}$ - different letters in the same row indicate differences $(\mathrm{P}<0.05)$.

SEM - standard error of the mean.

Table 3 - Levels of caffeine and antioxidant compounds in non-ensiled or ensiled coffee pulp

\begin{tabular}{|c|c|c|c|c|}
\hline \multirow{2}{*}{ Compound } & \multicolumn{2}{|c|}{ Treatments } & \multirow{2}{*}{ SEM } & \multirow{2}{*}{ P-value } \\
\hline & Non-ensiled coffee pulp & Ensiled coffee pulp & & \\
\hline Caffeine ( $\left.\mathrm{mg} \mathrm{g}^{-1} \mathrm{DM}\right)$ & $5.72 \mathrm{a}$ & $5.00 \mathrm{~b}$ & 0.22 & 0.038 \\
\hline Caffeic acid (mg g $\left.{ }^{-1} \mathrm{DM}\right)$ & $16.49 \mathrm{a}$ & $14.69 \mathrm{~b}$ & 0.59 & 0.024 \\
\hline Gallic acid (mg g $\left.{ }^{-1} \mathrm{DM}\right)$ & 2.88 & 2.58 & 0.25 & 0.357 \\
\hline Chlorogenic acid ( $\left.\mathrm{mg} \mathrm{g}^{-1} \mathrm{DM}\right)$ & 62.12 & 56.18 & 2.76 & 0.295 \\
\hline FRAP $\left(\mu \mathrm{mol}\right.$ trolox $\left.\mathrm{g}^{-1} \mathrm{DM}\right)$ & 215.66 & 206.59 & 13.59 & 0.647 \\
\hline
\end{tabular}

$\mathrm{a}, \mathrm{b}$ - different letters in the same row indicate differences $(\mathrm{P}<0.05)$.

SEM - standard error of the mean; FRAP - ferric reducing ability of plasma. 
Crude protein increased in ensiled coffee pulp, which might be due to a decrease of carbohydrates during the ensiling process, which in turn increased CP (Pedroso et al., 2005). Noriega Salazar et al. (2009) reported that the CP percentage in coffee pulp was higher as the ensiling time increased, observing the maximum $\mathrm{CP}$ levels at $120 \mathrm{~d}$ of ensiling. On the other hand, Bautista et al. (2005) found no increase in the CP percentage when evaluating coffee pulp not ensiled or ensiled with $50 \mathrm{~g}$ molasses $\mathrm{kg}^{-1}$ pulp, and ensiled with no additive. The average $\mathrm{CP}$ value for these was $85 \mathrm{~g} \mathrm{~kg}^{-1}$ DM. Moreover, Molina et al. (1990) reported $114.30 \mathrm{~g} \mathrm{~kg}^{-1} \mathrm{DM}$ crude protein in unfermented coffee pulp, while Figueroa and Mendoza (2010) reported $115 \mathrm{~g} \mathrm{~kg}^{-1} \mathrm{DM}$ protein in a typical variety of unfermented coffee pulp, similar to the value found in this study. It is possible that the differences found among authors are due to factors like ripeness, soil type, variety, or fertilization of the coffee fields. The coffee plantation where the samples for this research were collected is not fertilized, shaded, and under an organic production system. The higher NDF and ADF values found in the present study contrast those obtained by Molina et al. (1990), who observed that ensiling decreased NDF from 454 to $385 \mathrm{~g} \mathrm{~kg}^{-1} \mathrm{DM}$, and ADF from 442 to $370 \mathrm{~g} \mathrm{~kg}^{-1} \mathrm{DM}$, while Villalba et al. (2011) reported $615.80 \mathrm{~g} \mathrm{~kg}^{-1} \mathrm{NDF}$ and $372.10 \mathrm{~g} \mathrm{~kg}^{-1}$ DM ADF in coffee pulp ensiled with $50 \mathrm{~g}$ molasses $\mathrm{kg}^{-1}$ pulp. The differences among authors for the NDF, ADF, and CP could be due to factors similar to those reported for corn silage, where ripeness and variety modified these values (Vilela et al. 2008).

The soluble carbohydrates are mixed with the effluents during fermentation, while the fiber remains intact. Therefore, the fiber content increases during fermentation process and the percentages of NDF, ADF, and lignin could be greater. Pedroso et al. (2005), working with sugarcane, found that $\mathrm{CP}, \mathrm{ADF}, \mathrm{NDF}$, and lignin increased, given the great loss of soluble nutrients in the form of gases and effluents. In the present experiment, the increase could be due to the addition of $50 \mathrm{~g}_{\text {molasses }} \mathrm{kg}^{-1}$ pulp on top of the sugars already present in the coffee pulp, which could have been transformed into lactic acid or lost during the ensiling process, which in turn caused the levels of CP, ADF, NDF, and lignin to increase.

The caffeine values were lower than those reported by Barcelos et al. (2001), who observed an average of $8.70 \mathrm{mg} \mathrm{g}^{-1}$ in dehydrated coffee pulp from three varieties grown in Brazil. Molina et al. (1990), fermenting coffee pulp with urea and dicalcium phosphate and inoculated it with Aspergillus niger, found that the percentage of caffeine decreased from 9.80 to $7.2 \mathrm{mg} \mathrm{kg}^{-1}$. Although it has been reported that caffeine could be a limiting factor for animal feeding, different levels of coffee pulp inclusion into animal diets have been tested, ensiled or not, without causing any problems (Barrueta et al., 2000; Furuscho Garcia et al., 2000; Bautista et al., 2005).

Some compounds such as caffeic acid (Gülcin, 2006), gallic acid (Kim et al., 2008), and chlorogenic acid (Ohnishi et al., 1994), which have shown antioxidant capacity, have been found in coffee pulp, both ensiled and non-ensiled, before and after ensiling. Caffeic acid is a powerful antioxidant that is compared to alpha tocopherol (Gülcin, 2006).

Molina et al. (1990) reported that fermentation with Aspergillus niger decreases the concentration of polyphenols, without specifying the type of polyphenols. Besides the pulp, chlorogenic acid has been found in other coffee byproducts such as the cherry, skin, and grain of the coffee (Murthy and Naidu, 2012).

Torres-Mancera et al. (2011), using enzymatic extraction methods, found in coffee pulp $5.20 \mathrm{mg} / \mathrm{kg}$ hidroxicinamic acids, of which $58.70 \%$ corresponded to chlorogenic acid, $37.60 \%$ to caffeic acid, $2.10 \%$ to ferulic acid, and $1.50 \%$ to p-coumaric acid. These authors pointed out the importance of extracting these compounds, since they present anticarcinogenic, anti-inflammatory and antioxidant properties. In the present research, chlorogenic was the highest among the antioxidants found, followed by caffeic acid. However, contrary to Torres-Mancera et al. (2011), gallic acid was detected in concentrations of $2.88 \mathrm{mg} \mathrm{g}^{-1} \mathrm{DM}$ in non-ensiled coffee pulp and $2.58 \mathrm{mg} \mathrm{g}^{-1} \mathrm{DM}$ in ensiled coffee pulp.

Arellano-González et al. (2011) reported that fermentation of coffee pulp with Aspergillus tamari decreased the total content of hidroxicinamic acids by $34 \%$. However, the content of free hidroxicinamic acids, which are not linked to the cell wall, increased by $134 \%$. These authors attributed these changes to the enzymatic action of Aspergillus tamari on the cell wall, which in turn explains the antioxidizing properties of fermented coffee pulp.

The caffeic acid present in coffee pulp can be partly responsible for its antioxidant capacity. Gülcin (2006), measuring the capacity of this compound, found that caffeic acid has $20.10 \%$ more antioxidant capacity than trolox, which is analogous to alpha tocopherol, and $54-70 \%$ more than tocopherol.

Although gallic acid was found in a lower amount than chlorogenic acid and caffeic acid, it might contribute to the antioxidant activity of coffee pulp. Gallic acid has been proven to have a greater hydrogen peroxide trapping activity, followed by caffeic acid, and then by chlorogenic acid (Sroka and Cisowski, 2003). Sato et al. (2011) found 
that caffeic acid has a greater antioxidant activity than chlorogenic acid when evaluating the in vitro and in vivo antioxidant properties of caffeic acid and chlorogenic acid.

The antioxidant capacity found for coffee pulp in the present study was greater than that of cocoa fiber (73.32 $\left.\mu \mathrm{mol} \mathrm{g}^{-1} \mathrm{DM}\right)$, which contains phenolic compounds that have been proven to be absorbed increasing the antioxidant capacity in rat serum (Lecumberri et al., 2006). In the case of coffee drinks, it has been reported that the type of preparation modified their antioxidant capacity; Sánchez-González et al. (2005) found $199.00 \mu \mathrm{mol} \mathrm{g} \mathrm{g}^{-1} \mathrm{DM}$ in Italian coffee, $162.00 \mu \mathrm{mol} \mathrm{g}^{-1} \mathrm{DM}$ in espresso, and $236.00 \mu \mathrm{mol} \mathrm{g}^{-1} \mathrm{DM}$ in filtered coffee.

Li et al. (2008), evaluating 45 medicinal plants in China with different concentrations of polyphenols, reported different trolox concentrations, 42 of which were lower than those found for coffee pulp; Paeonia lactiflora Pall and Paeonia suffruticosa Andr were similar, and only Sargento doxacuneata Rehd. Et Wils showed greater a trolox content $(\mu \mathrm{mol} / \mathrm{g}$ ) than those found in the present study. Likewise, trolox concentrations in coffee pulp were greater than those found by Tiveron et al. (2012) in 23 different plants grown in Brazil.

Because of current production practices such as supplementing animals with polyunsaturated fatty acids, which increases susceptibility to lipoperoxidation (Gladine et al., 2007a), and some critical physiological events such as gestation (Garrel et al., 2010), postpartum transition (Gitto et al., 2002), in management practices such as synchronization protocols (Sönmez et al., 2009), or to improve shelf life of meat products (Karre et al., 2013), coffee pulp could be an agricultural byproduct with a great potential to reduce oxidative stress in animals during highdemanding physiological stages, due to its high antioxidant capacity. Several studies have been conducted to evaluate the use of natural antioxidants in animal response. Studying four different plants rich in polyphenols, Gladine et al. (2007b) determined that they had a high antioxidizing capacity. They were also efficient in reducing lipoperoxidation in diets with polyunsaturated fatty acids (Gladine et al., 2007a). Thyme leaves (Thymus zygis ssp. gracilis) have been proved to have antioxidant activity, by reducing oxidation of meat from lambs from ewes supplemented with these leaves during gestation (Nieto et al., 2011). The extract of verbenaceae leaves (Lippia spp.), which contains $1.75 \mathrm{~g} \mathrm{~kg}^{-1}$ gallic acid, among other phenols, has proven to reduce oxidation levels in plasma of postpartum ewes (Casamassima et al., 2012). Other plants, such as rosemary, grapes, citrics, and marigold are also efficient in reducing lipoperoxidation in plasma (Gladine et al., 2007b).
It has been proven that besides the coffee grain, which is used for human drinks, and toasted grain residues, which show antioxidant properties (Yen et al., 2005), coffee pulp is a highly available agricultural byproduct in coffee-growing zones, and has an acceptable nutritional value. According to the findings of the present research, coffee pulp had a high polyphenol content besides its antioxidant capacity, which could be used to protect animals from oxidative stress, since it has been proven that the antioxidant properties of polyphenol-rich plants are not inhibited during digestion even in ruminants (Gladine et al., 2007b).

\section{Conclusions}

Ensiling coffee pulp is a viable process. Coffee pulp provides conditions for a good fermentation. When it is ensiled with $50 \mathrm{~g}$ molasses $\mathrm{kg}^{-1}$ fresh pulp, the crude protein, acid detergent fiber, neutral detergent fiber and lignin contents increase. Antioxidant compounds, such as chlorogenic acid, caffeic acid and gallic acid are found in coffee pulp. Caffeic acid decreases due to the ensiling process; however, the antioxidant capacity of coffee pulp remains unchanged.

\section{Acknowledgments}

The authors thank the partial funding to this research to Linea Prioritaria de Investigación, LPI-11 from the Colegio de Postgraduados and the project DGAPA/PAPIIT: IT222611-3 of Universidad Nacional Autónoma de México.

\section{References}

AOAC - Association of Official Analytical Chemist. 1990. Official methods of analysis. 15th ed. AOAC, Washington, D.C.

Arellano-González, M. A.; Ramírez-Coronel, M. A.; Torres-Mancera, M. T.; Pérez-Morales, G. G. and Saucedo-Castañeda, G. 2011. Antioxidant activity of fermented and nonfermented coffee (Coffea arabica) pulp extracts. Food Technology and Biotechnology 49:374-378.

Barcelos, A. F.; Paiva, P. C. A.; Pérez, J. R. O.; Santos, V. B. and Cardoso, R. M. 2001. Fatores antinutricionais da casca e da polpa desidratada de café (Coffea arabica L.) armazenadas em diferentes períodos. Revista Brasileira de Zootecnia 30:1325-1331.

Barrueta, D. E.; Bautista, E. O. and Acevedo, L. 2000. Pulpa de café ensilada en dietas para cerdos en crecimiento y engorde. Revista Facultad de Ciencias Veterinarias 41:85-90.

Bautista, E. O.; Pernia, J.; Barrueta, D. and Useche, M. 2005. Pulpa ecológica de café ensilada en la alimentación de alevines del híbrido Cachamay (Colossoma Macropomum x Piaractus Brachypomus). Revista Científica Universidad de Zulia 15:33-40.

Benzie, I. F. F. and Strain, J. J. 1999. Ferric reducing/antioxidant power assay: direct measure of total antioxidant activity of biological fluids and modified version for simultaneous measurement of total antioxidant power and ascorbic acid concentration. Methods Enzymology 299:15-27.

Casamassima, D.; Palazzo, M.; Martemucci, G.; Vizzarri, F. and Corino, C. 2012. Effects of verbascoside on plasma oxidative status 
and blood and milk production parameters during the peripartum period in Lacaune ewes. Small Ruminant Research 105:1-8.

Castillo, M. D.; Ames, J. M. and Gordon, M. H. 2002. Effect of roasting on the antioxidant activity of coffee brews. Journal of Agricultural and Food Chemistry 50:3698-3703.

Duarte, S. M. S.; Abreu, C. M. P.; Menezes, H. C.; Santos, M. H. and Gouvêa, C. M. C. P. 2005. Effect of processing and roasting on the antioxidant activity of coffee brews. Food Science and Technology 25:387-393.

Erwin, E. S.; Marco, G. J. and Emery, E. M. 1961. Volatile fatty acid analysis of blood and rumen fluid by gas chromatography. Journal of Dairy Science 44:1768-1771.

Farah, A. and Donangelo, C. M. 2006. Phenolic compounds in coffee. Brazilian Journal of Plant Physiology 18:23-36.

Figueroa, H. J. and Mendoza, A. J. 2010. Cuantificación de minerales $\mathrm{K}, \mathrm{Ca}, \mathrm{Mg}$ y $\mathrm{P}$ en pulpa y pergamino de café (Coffea arabica $\mathrm{L}$. var. Typica). Revista Venezolana de Ciencia y Tecnología de Alimentos 1:221-230.

Furuscho Garcia, I. F.; Perez, J. R. O.; Teixeira, J. C. and Barbosa, C. M. P. 2000. Desempenho de cordeiros Texel x Bergamácia, Texel x Santa Inês e Santa Inês puros, terminados em confinamento, alimentados com casca de café como parte da dieta. Revista Brasileira de Zootecnia 29:564-572.

Garrel, C.; Fowler, P. A. and Al-Gubory, K. H. 2010. Developmental changes in antioxidant enzymatic defenses against oxidative stress in sheep placentomes. Journal of Endocrinology 205:107-116.

Gitto, E.; Reiter, R. J.; Karbownik, M.; Tan, D. X.; Gitto, P.; Barberi, S. and Barberi, I. 2002. Causes of oxidative stress in the pre- and perinatal period. Neonatology 81:146-157.

Gladine, C.; Morand, C.; Rock, E.; Bauchart, D. and Durand, D. 2007a. Plant extracts rich in polyphenols (PERP) are efficient antioxidants to prevent lipoperoxidation in plasma lipids from animals fed $n-3$ PUFA supplemented diets. Animal Feed Science and Technology 136:281-296.

Gladine, C.; Rock, E.; Morand, C.; Bauchart, D. and Durand, D. 2007b. Bioavailability and antioxidant capacity of plant extracts rich in polyphenols, given as a single acute dose, in sheep made highly susceptible to lipoperoxidation. British Journal of Nutrition 98:691-701.

Gülcin, I. 2006. Antioxidant activity of caffeic acid (3,4dihydroxycinnamic acid). Toxicology 217:213-220.

Hristov, A. N. and McAllister, T. A. 2002. Effect of inoculants on whole-crop barley silage fermentation and dry matter disappearance in situ. Journal of Animal Science 80:510-516.

INEGI - Instituto Nacional de Estadística y Geografía. 2011. México. Available at: $<\mathrm{http} / /$ www.inegi.org.mx/sistemas/mexicocifras/ default.aspx? $=20>$. Accessed on: Jan. 28, 2013.

Jaurena, G. 2008. Contribución de la inoculación bacteriana a la fermentación de silajes de planta entera de maíz y sorgo. Revista Argentina de Producción Animal 28:21-29.

Karre, L.; Lopez, K. and Getty, K. J. K. 2013. Natural antioxidants in meat and poultry products. Meat Science 94:220-227.

Kim, J. H.; Kang, N. J.; Lee, B. K.; Lee, K. W.; and Lee, H. J. 2008. Gallic acid, a metabolite of the antioxidant propyl gallate, inhibits gap junctional intercellular communication via phosphorylation of connexin 43 and extracellular-signal-regulated kinase $1 / 2$ in rat liver epithelial cells. Mutation Research 638:175-183.

Lecumberri, E.; Mateos, R.; Ramos, S.; Alía, M.; Rúperez, P.; Goya, L.; Izquierdo-Pulido, M. and Bravo, L. 2006. Caracterización de la fibra de cacao y su efecto sobre la capacidad antioxidante en suero de animales en experimentación. Nutrición Hospitalaria 21:622-628.

Li, H. B.; Wong, C. C.; Cheng, K. W. and Chen, F. 2008. Antioxidant properties in vitro and total phenolic contents in methanol extracts from medicinal plants. LWT 41:385-390.

Mazzafera, P. 2002. Degradation of caffeine by microorganisms and potential use of decaffeinated coffee husk and pulp in animal feeing. Scientia Agricola 59:815-821.

Molina, M.; Lechuga, O. R. and Bressani, R. 1990. Valor nutritivo de la pulpa de café sometida a fermentación sólida usando
Aspergillus niger en pollos y cerdos. Agronomía Mesoamericana 1:79-82.

Murthy, P. S. and Naidu, M. M. 2012. Recovery of phenolic antioxidants and functional compounds from coffee industry byproducts. Food Bioprocess Technology 5:897-903.

Nieto, G.; Bañon, S. and Garrido, M. D. 2011. Effect of supplementing ewes' diet with thyme (Thymus zygis ssp. gracilis) leaves on the lipid oxidation of cooked lamb meat. Food Chemistry 125:1147-1152.

Noriega Salazar, A.; Silva Acuña, R. and García de Salcedo, M. 2009. Composición química de la pulpa de café a diferentes tiempos de ensilaje para su uso potencial en la alimentación animal. Zootecnia Tropical 27:135-141.

Ohnishi, M.; Morishita, H.; Iwahashi, H.; Toda, S.; Shirataki, Y.; Kimura, R. and Kido, R. 1994. Inhibitory effects of chlorogenic acids on linoleic acid peroxidation and haemolysis. Phytochemestry 36:579-583.

Orozco, A. L.; Pérez, M. I.; Guevara, O.; Rodríguez, J.; Hernández, M.; González-Vila, F. J.; Polvillo, O. and Arias, M. E. 2008. Biotechnological enhancement of coffee pulp residues by solidstate fermentation with Streptomyces.Py-GC/MS analysis. Journal of Analytical and Applied Pyrolysis 81:247-252.

Pedroso, A. F.; Nussio, L. G.; Paziani, S. F.; Loures, D. R. S.; Igarasi, M. S.; Coelho, R. M.; Packer, I. H.; Horii, J. and Gomes, L. H. 2005. Fermentation and epiphytic microflora dynamics in sugar cane silage. Scientia Agricola 62:427-432.

Restrepo-Sánchez, D. C.; Narváez-Cuenca, C. E. and Restrepo-Sánchez, L. P. 2009. Extracción de compuestos con actividad antioxidante de frutos de guayaba cultivada en Vélez-Santander, Colombia. Química Nova 32:1517-1522.

Richelle, M.; Tavazzi, I. and Offord, E. 2001. Comparison of the antioxidant activity of commonly consumed polyphenolic beverages (coffee, cocoa, and tea) prepared per cup serving. Journal of Agricultural and Food Chemistry 49:3438-3442.

Ryser, E. T.; Arimi, S. M. and Donnelly, C. W. 1997. Effects of pH on distribution of listeria ribotypes in corn, hay, and grass silage. Appplied and Environmental Microbioloy 63:3695-3697.

Sánchez-González, I.; Jiménez-Escrig, A. and Saura-Calixto, F. 2005. In vitro antioxidant activity of coffees brewed using different procedures (Italian, espresso and filter). Food Chemistry 90:133139.

Sato, Y.; Itagaki, S.; Kurokawa, T.; Ogura, J.; Kobayashi, M.; Hirano, T.; Sugawara, M. and Iseki, K. 2011. In vitro and in vivo antioxidant properties of chlorogenic acid and caffeic acid. International Journal of Pharmaceutics 403:136-138.

Sönmez, M.; Bozkurt, T.; Türk, G.; Gür, S.; Kizil, M. and Yüce, A. 2009. The effect of vitamin E during preovulatory period on reproductive performance of goats following estrous synchronization using intravaginal sponges. Animal Reproduction Science 114:183-192.

Sroka, Z. and Cisowski, W. 2003. Hydrogen peroxide scavenging, antioxidant and anti-radical activity of some phenolic acids. Food and Chemical Toxicology 41:753-758.

Tagliari, C. V.; Sanson, R. K.; Zanette, A.; Franco, T. T. and Soccol, C. R. 2003. Caffeine degradation by rhizopus delemar in packed bed column bioreactor using coffee husk as substrate. Brazilian Journal of Microbiology 34:102-104.

Taylor, K. A. C. 1996. A simple colorimetric assay for muramic acid and lactic acid. Applied Biochemistry and Biotechnology 56:49-58.

Tiveron, A. P.; Melo, P. S.; Bergamaschi, K. B.; Vieira, T. M. F. S.; Regitano-d'Arce, M. A. B. and Alencar, S. M. 2012. Antioxidant activity of Brazilian vegetables and its relation with phenolic composition. International Journal Molecular Sciences 13:8943-8957.

Torres-Mancera, M. T.; Córdova-López, J.; Rodríguez-Serrano, G.; Roussos, S.; Ramírez-Coronel, A.; Favela-Torres, E. and SaucedoCastañeda, G. 2011. Enzymatic extraction of hydroxycinnamic acids from coffee pulp. Food Technology Biotechnology 49:369-373.

Ulloa Rojas, J. B.; Verreth, J. A. J.; Amato, S. and Huisman, E. A. 2003. Biological treatments affect the chemical composition of coffee pulp. Bioresource Technology 89:267-274. 
Van Soest, P. J.; Robertson, J. B. and Lewis, B.A. 1991. Methods for dietary fiber, neutral fiber and no starch polysaccharides in relation to nutrition. Journal of Dairy Science 74:3583-3597.

Vilela, H. H.; Rezende, A.V.; Vieira, P. F.; Andrade, G. A.; Evangelista, A. R. and Almeida, G. B. S. 2008. Valor nutritivo de silagens de milho colhido em diversos estádios de maturação. Revista Brasileira de Zootecnia 37:1192-1199.
Villalba, D. K.; Holguin, V. A.; Acuña, J. A. and Piñeros, V. R. 2011. Calidad bromatológica y organoléptica de ensilajes de residuos orgánicos del sistema de producción café-musáceas. Revista Colombiana de Ciencia Animal 4:47-52.

Yen, W. J.; Wang, B. S.; Chang, L. W. and Duh, P. D. 2005. Antioxidant properties of roasted coffee residues. Journal of Agricultural and Food Chemistry 53:2658-2663. 